Article

\title{
Functional Characterization of a Bidirectional Plant Promoter from Cotton Leaf Curl Burewala Virus Using an Agrobacterium-Mediated Transient Assay
}

\author{
Muhammad Aleem Ashraf *, Ahmad Ali Shahid, Abdul Qayyum Rao, Kamran Shehzad Bajwa \\ and Tayyab Husnain
}

Plant Biotechnology Laboratory, Centre of Excellence in Molecular Biology (CEMB), University of the Punjab, Lahore 53700, Pakistan; E-Mails: ahmadali.shahid@gmail.com (A.A.S); qayyumabdu177@yahoo.com (A.Q.R); kamrancembian@yahoo.com (K.S.B); tayyabhusnain@yahoo.com (T.H.)

* Author to whom correspondence should be addressed; E-Mail: muhammad.aleem@cemb.edu.pk; Tel.: +92-33-3634-6277; Fax: +92-42-3529-3141.

Received: 14 October 2013; in revised form: 14 December 2013 / Accepted: 24 December 2013 / Published: 14 January 2014

\begin{abstract}
The $\mathrm{C} 1$ promoter expressing the $\mathrm{AC} 1$ gene, and $\mathrm{V} 1$ promoter expressing the AV1 gene are located in opposite orientations in the large intergenic region of the Cotton leaf curl Burewala virus $(\mathrm{CLCuBuV})$ genome. Agro-infiltration was used to transiently express putative promoter constructs in Nicotiana tabacum and Gossypium hirsutum leaves, which was monitored by a GUS reporter gene, and revealed that the bidirectional promoter of $\mathrm{CLCuBuV}$ transcriptionally regulates both the $\mathrm{AC} 1$ and $\mathrm{AV} 1$ genes. The $\mathrm{CLCuBuV} \mathrm{C1}$ gene promoter showed a strong, consistent transient expression of the reporter gene (GUS) in N. tabacum and G. hirsutum leaves and exhibited GUS activity two- to three-fold higher than the CaMV $35 \mathrm{~S}$ promoter. The $\mathrm{CLCuBuV}$ bidirectional gene promoter is a nearly constitutive promoter that contains basic conserved elements. Many cis-regulatory elements (CREs) were also analyzed within the bidirectional plant promoters of $\mathrm{CLCuBuV}$ and closely related geminiviruses, which may be helpful in understanding the transcriptional regulation of both the virus and host plant.
\end{abstract}

Keywords: cotton leaf curl Burewala virus; agro-infiltration; bidirectional promoter; cis-regulatory elements; geminivirus 


\section{Introduction}

Geminiviruses are plant pathogens with small, circular single stranded (ss) DNA genomes of 2.5-3.0 kb that are encapsidated in characteristic twin quasi-icosahedral particles. These viruses are differentiated into four genera (Topocuvirus, Curtovirus, Mastrevirus, Begomovirus) based upon genome organization, insect vector, and sequence homology [1,2]. Geminiviruses serve as a good source for regulatory elements, which can be used to drive transgene expression in plants. Promoters from Cauliflower mosaic virus (CaMV) [3], Cotton leaf curl Multan virus (CLCuMuV) [4], and Strawberry vein banding virus (SVBV) [5] display strong and consistent constitutive expression in transgenic plants. The large intergenic region (LIR) of the DNA-A component from the monopartite begomovirus genome contains plant cis-acting DNA regulatory elements and transcription factor binding sites (TFBs) required for the control of viral gene expression and replication [6]. Sequence and functional characterization of large intergenic regions (LIR) from monopartite and common regions from bipartite geminiviruses Digitaria streak virus (DSV) [7], Tomato golden mosaic virus (TGMV) [8-11], African cassava mosaic virus (ACMV) [12-15], Maize streak virus (MSV) [16], Cotton leaf curl Multan (CLCuMuV) [4], Wheat dwarf geminivirus (WDG) [17], Mungbean yellow mosaic India virus (MYMIV) [18], and Mungbean yellow mosaic geminivirus (MYMV) [19] revealed that this region, which is located between the $5^{\prime}$ ends of the first complementary and virion sense open reading frames (ORFs), possesses promoter activity and is essential for the bidirectional transcription of both complementary (Rep) and virion (Cp) genes. In the case of ACMV, TGMV, CLCuMuV, and MYMIV, the LIR has much stronger promoter activity in the complementary sense than in the virion sense in the absence of transcriptional activator protein C2 [4,8,12,18,20].

Transcription of the replication associated protein (Rep) gene and coat protein (Cp) gene is governed by a bidirectional promoter that is present in the large intergenic region (LIR). Rep downregulates its own expression by binding to an iterative motif located between the TATA box and transcription start site [20]. The LIR also possesses an origin of replication (ori) for the viral genome. The stem-loop structure motif and iterated elements $(8-13 \mathrm{nt})$ have been identified in the vicinity of the putative TATA box in the complementary $(\mathrm{C} 1)$ sense promoter [21,22]. The iterated elements have been suggested to play pivotal roles in both the replication and transcriptional repression of complementary sense genes [22].

Cotton leaf curl Burewala virus $(\mathrm{CLCuBuV})$ is a whitefly-transmitted monopartite begomovirus that infects cotton and has a recombinant genome composed of sequences derived from the Cotton leaf curl Multan virus (CLCuMuV) and Cotton leaf curl Kokhran virus (CLCuKoV) [23-25]. The DNA-A component of the monopartite begomovirus genome is organized into six open reading frames (ORFs), C1 (Rep), C2 (Trap), C3, C4, V1 (CP), and V2, which are transcribed bidirectionally from the LIR [6,26,27].

In this study, Agrobacterium-mediated delivery into plants was used as a transient assay system to qualitatively, as well as quantitatively study promoter activity. The LIR sequence from the CLCuBuV genome was isolated, and $\mathrm{CLCuBuV} \mathrm{C1}$ and $\mathrm{V} 1$ promoter activity was investigated using GUS reporter gene transient expression in plants. We found that the $\mathrm{CLCuBuV} \mathrm{C1}$ promoter had strong and consistent transient expression in plant leaves compared to the CLCuBuV V1 and CaMV 35S promoters. The present study was designed to characterize the bidirectional gene promoter of CLCuBuV to use it in 
recombinant DNA technology to combat the spatio-temporal expression pattern of an insecticidal gene $($ CrylAc) in transgenic cotton in the future.

\section{Experimental Section}

\subsection{Plant Material and Bacterial Strain}

Seeds from a cotton (G. hirsutum) cultivar (MNH-786) were grown in composite soil (peat, sand, soil 1:1:1) in greenhouse at $25+2{ }^{\circ} \mathrm{C}$. Seeds from tobacco (N. tabacum) were grown in loamy soil in a farmhouse at Chak No.59/F Hasilpur, Pakistan. After four weeks, the plants were moved greenhouse. Seeds from legumes (Mung bean, French bean, and Cow pea) were grown in Murashige and Skooge (MS) medium under a $16 \mathrm{~h}$ light and $8 \mathrm{~h}$ dark cycle at $22{ }^{\circ} \mathrm{C}$. After one week, the older plants were subjected to transient expression. The Escherichia coli strain DH5a cells were used to clone all of the recombinant plasmid vectors. The Agrobacterium tumefaciens strain LBA4404 was used for the leaf and root infiltration.

\subsection{Isolation of $C L C u B u V$ Bidirectional Promoter}

Based on the characterized CLCuBuV genome, 455 bp fragments from both CLCuBuV C1 and V1 were amplified from a $\mathrm{CLCuBuV}$ genomic plasmid using promoter-specific primer sets. These primers were designed from the LIR of the CLCuBuV genomic clone (accession number FR750318) using the Primer 3 online software version 0.4 [28]. The PCR conditions were as follows; $94{ }^{\circ} \mathrm{C}$ for $3 \mathrm{~min}$ followed by 30 cycles of $94{ }^{\circ} \mathrm{C}$ for $45 \mathrm{~s}, 58{ }^{\circ} \mathrm{C}$ for $30 \mathrm{~s}$, and $72{ }^{\circ} \mathrm{C}$ for $45 \mathrm{~s}$, followed by a final extension at $72{ }^{\circ} \mathrm{C}$ for 5 min while the final holding temperature was $4{ }^{\circ} \mathrm{C}$. The primer sets were as follows:

(i) 5'- CCATGGTGACTTTGGTTTAGAGACAACAAC-3' and

5'- CTGCAGTAATTCCTAGCCCTTATTACCAG-3'

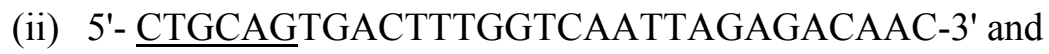

5'- CCATGGTAATTCCTAGCCCTTATTACCAG-3'

The underlined sequences are the restriction enzyme sites engineered for cloning of both promoters. The contents of the $20 \mu \mathrm{L}$ reaction PCR reaction were: $10 \mu \mathrm{L}$ PCR master mix (Thermo Fisher Scientific, Waltham, MA, USA), forward primer $1 \mu \mathrm{L}(10 \mu \mathrm{M})$, reverse primer $1 \mu \mathrm{L}(10 \mu \mathrm{M})$, template $0.5 \mu \mathrm{L}$, and $7.5 \mu \mathrm{L}$ of PCR grade DNase/RNase-free distilled water (Invitrogen, Carlsbad, CA, USA). The amplicons were separated on $1.5 \%$ agarose gel in Tris-Acetate-EDTA buffer, $\mathrm{pH} 8.0$ and stained using ethidium bromide staining. Bands were visualized under UV on gel documentation system. The amplicons were cloned into an Invitrogen TA vector $\left(\mathrm{pCR}^{\circledR} 2.1\right)$.

\subsection{Plasmid Construction}

The binary vector pCAMBIA1301 (Cambia, Canberra, Australia) was used in the Agrobacterium transient plant transformation experiment. The T-DNA region of pCAMBIA1301 includes a selectable marker gene construct for hygB resistance and CaMV 35S promoter upstream of the GUS reporter gene. The CaMV $35 \mathrm{~S}$ promoter was removed by excision of the Nco I-Pst I fragment containing 
the $35 \mathrm{~S}$ promoter. The $\mathrm{CLCuBuV} \mathrm{C} 1$ and $\mathrm{V} 1$ promoters were digested from the TA vector using the Nco I-Pst I restriction enzymes and subsequently cloned into pre-digested pCAMBIA1301 at the desired sites. The resulting plasmids were named pC1GUS1301 and pV1GUS1301. The integration of the promoters in both constructs was confirmed by restriction enzyme digestion and PCR.

\subsection{Sequence Analysis}

The bidirectional promoter sequence was analyzed for the presence of cis-regulatory elements using the Plant Cis-Acting Regulatory Element (PlantCARE) database [29]. To identify the TFBs, we analyzed the activity of $c i$-elements using PLAnt Cis-acting Elements (PLACE) database [30]. The program SIGSCAN version 4.0.5 was used to search for more TFBs from the TRANScription FACtor database (TRANSFAC) database [31]. The transcription start site (TSS) was predicted using the Neural Network Promoter Prediction (NNPP) server [32]. Nucleotide sequence comparisons were performed using the CLUSTALW algorithm in the MegAlign program using the default settings in the Lasergene software from DNASTAR Inc. (Madison, WI, USA). The overrepresented CREs were identified using the MEME (Multiple EM for Motif Elicitation) tool version 4.4.0 [33]. The sequence logo was obtained from JAPSAR database [34].

\subsection{Preparation of the Agrobacterium Suspension}

Approximately $250 \mu \mathrm{L}$ of the $A$. tumefacience strain of LBA4404 containing individual constructs was inoculated in $5 \mathrm{~mL}$ of YEP solution supplemented with kanamycin $(50 \mu \mathrm{g} / \mu \mathrm{L})$ and grown at $28{ }^{\circ} \mathrm{C}$ for two days while shaking at $180 \mathrm{rpm}$. Approximately $500 \mu \mathrm{L}$ of Agrobacteria was then transferred to $50 \mathrm{~mL}$ of fresh YEP solution containing $10 \mathrm{mM}$ MES, $20 \mu \mathrm{M}$ acetosyringone and kanamycin at the same final concentration as above. After $24 \mathrm{~h}$ in culture $\left(28^{\circ} \mathrm{C}, 180 \mathrm{rpm}\right)$, the Agrobacterium cells were collected by centrifugation for $10 \mathrm{~min}$ at 3,000 rpm and resuspended to an $\mathrm{OD}_{600}$ of $0.6-0.9$ in suspension solution (MS medium supplemented with $10 \mathrm{mM}$ MES and $200 \mathrm{mM}$ acetosyringone) and incubated at room temperature for $2 \mathrm{~h}$ before Agroinfiltration.

\subsection{Agrobacterium-Mediated Infiltration}

Agrobacterium-mediated transient transformation of the tobacco and cotton leaves was conducted in middle-sized to near fully expanded leaves that were still attached to old transplanted plant seedlings. The experiment was repeated on three individual plants with five infiltrations each. Using a $1 \mathrm{~mL}$ syringe, $500 \mu \mathrm{L}$ of the bacterial suspension was infiltrated into the intercellular spaces on the abaxial side of each intact leaf. The infiltrated borders were marked with a permanent marker. The plants were placed into a phytotron and analyzed after three days. Agroinoculation was carried out in the root-hypocotyl axis region of old sprouted seeds of Cowpea, French bean and Mung bean. After $72 \mathrm{~h}$, the seedlings were trimmed, washed well to remove traces of the Agrobacterium culture on the surface and used for qualitative and quantitative assays of the reporter gene GUS. 


\subsection{Histochemical Detection of GUS Activity}

GUS activity was histochemically detected by incubating overnight at $37{ }^{\circ} \mathrm{C}$ in staining solution composed of $0.1 \% \mathrm{w} / \mathrm{v}$ 5-bromo-4-chloro-3-indolyl- $\beta$-D-glucoronic acid (X-Gluc; Sigma, St. Louis, MO, USA) in $100 \mathrm{mM} \mathrm{Na}_{2} \mathrm{HPO}_{4} \mathrm{pH} 7.0,0.01 \% \mathrm{w} / \mathrm{v}$ Chloramphenicol, 20\% Triton X-100, 20\% v/v Methanol. Chlorophyll was extracted from the photosynthetic tissues with $70 \% \mathrm{v} / \mathrm{v}$ ethanol. Transient GUS expression was detected microscopically by visualizing the distinct blue color that results from the enzymatic cleavage of X-Gluc. The samples were stored at $4{ }^{\circ} \mathrm{C}$ in $70 \% \mathrm{v} / \mathrm{v}$ ethanol.

\subsection{Fluorometric Determination of GUS Activity}

The infiltrated marked leaf and root areas were excised and frozen in liquid nitrogen. The frozen plant tissue was ground into a fine powder. After grinding, $1.0 \mathrm{~mL}$ of extraction buffer was mixed and centrifuged for $10 \min (13,000 \mathrm{rpm})$ at $4{ }^{\circ} \mathrm{C}$. A $5 \mu \mathrm{L}$ aliquot of supernatant was mixed with $400 \mu \mathrm{L}$ of pre-warmed $\left(37^{\circ} \mathrm{C}\right)$ GUS assay solution. The mixture was incubated at $37{ }^{\circ} \mathrm{C}$, and $1.6 \mu \mathrm{L}$ of the stop buffer $\left(0.2 \mathrm{M} \mathrm{Na}_{2} \mathrm{CO}_{3}\right)$ was added after $15 \mathrm{~min}$. The stop buffer and $50 \mathrm{nM}$ to $1 \mu \mathrm{M}$ of 4-methylumbelliferone (4-MU) was used for calibration and standardization. The relative fluorescence was measured using a TKO 100 fluorometer (Hoefer Scientific Instruments, San Francisco, CA, USA) with an excitation wavelength of $360 \mathrm{~nm}$ and an emission wavelength of $465 \mathrm{~nm}$. The detected fluorescence was expressed in relative fluorescence units (RFU) (1pM-4MU is equal to $1 \mathrm{RFU} \mathrm{mg}{ }^{-1}$ protein $\min ^{-1}$ ). The protein concentrations were estimated by performing the Bradford assay [35]: $20 \mu \mathrm{L}$ extract was mixed with $780 \mu \mathrm{L} 1 \times$ PBS buffer and added to $200 \mu \mathrm{L}$ dye reagent concentrate (Bio-Rad, München, Germany). Sterile water (dye reagent added) was used for reference setting and $10 \mathrm{mg} / \mathrm{mL}$ to $100 \mathrm{mg} / \mathrm{mL}$ bovine serum albumin (Sigma, Steinheim, Germany) (dye reagent added) were used as standards. Protein concentration in the extract was determined using a standards-based calibration curve (exponential) established with Microsoft Excel.

\subsection{Statistical Analysis}

The quantification expression data was analyzed statistically by using ANOVA and Tukey's HSD (honest significant difference) and Fisher's LSD (least significant difference) (individual and pairwise) for completely randomized designs (CRD) by using a Statistix 8.1 software. $p$ value of $<0.05$ was considered as statistically significant.

\section{Results}

\subsection{Structure and Sequence Analysis}

The CLCuBuV bidirectional gene promoters were isolated from the LIR of the DNA-A genomic clone from $\mathrm{CLCuBuV}$, as previously characterized [25]. The complete DNA-A component of the $\mathrm{CLCuBuV}$ genome has been reported (Genbank accession number: FR750318 CLCuBuV-MV12). The nucleotide sequence of the $\mathrm{CLCuBuV}$ bidirectional gene promoter ( $\mathrm{CLCuBuV}$ genomic coordinates 2595-292 bp) is shown in (Figure 1). 
Figure 1. The 455 bp DNA sequence of the full-length transcript of the bidirectional gene promoter of the $\mathrm{CLCuBuV}$ coordinates from 2595-292 nucleotides in the viral genome. The putative motifs are in bold and underlined. The replication initiation site/putative stem-loop motif was composed of 35 bp consisting of ATC-motif (GGCCATCC) and GC-rich region (GGCCGCGC) around the nonanucleotide. The conserved late element (CLE) was present at position +185 was suggested to functional target for $\mathrm{C} 2$. The POLASIG3 motif (AATAAT) was also identified at position +242 . The TATA-box for Rep promoter was found at position 65 nucleotide and TATA-box for Cp promoter was located at position 259 nucleotide in the LIR. The Box-II are predicted at position 433 in the LIR. MBS (MYB drought responsive element) was found at position 20 within the LIR. The labeling of motifs are indicated above the line. The right-side numbering shows the position of LIR in the genome.

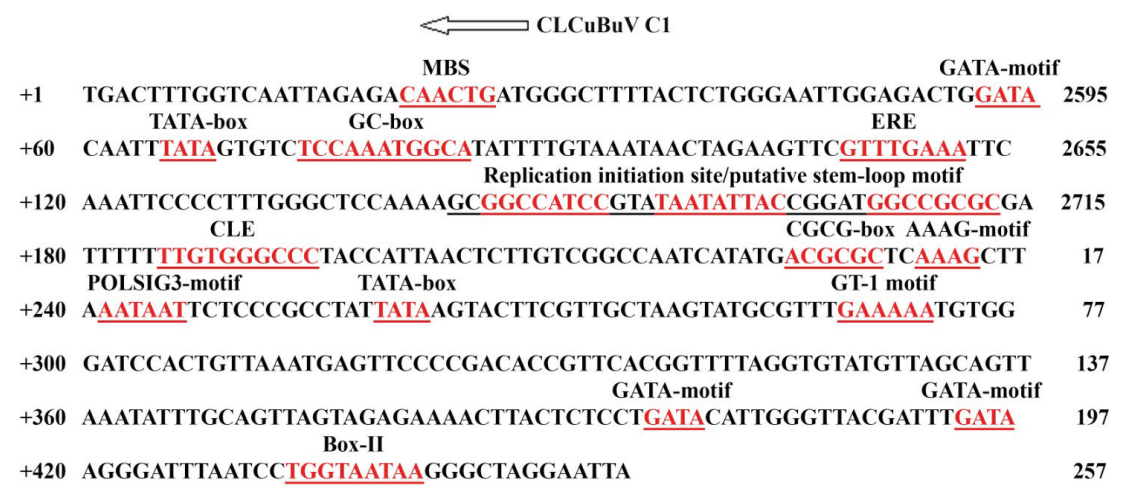

CLCuBuVV1

The cloning of both promoters is represented in Figure 2. The bidirectional promoter sequence contains several consensus eukaryotic regulatory domains, such as TATA, GC-rich, and CAAT boxes, which are present in almost all geminivirus LIRs [21,36]. The LIR consisted of $455 \mathrm{bp}$ and contained cis-acting DNA elements that are involved in begomovirus replication and transcriptional regulation, including a Rep-binding site (iterons), TATA boxes, GC boxes, and stem-loop elements that contain the conserved nonanucleotide (TAATATTAC) sequence. The TATA box is located $30 \mathrm{bp}$ upstream of the transcription start site. The TATA boxes and GC-rich box have been shown to be essential for geminivirus promoter activity within the LIR. The putative CLE (TTGTGGGCCC) was suggested to be a potential functional target for $\mathrm{C} 2$ to trans-activate virion sense gene transcription [21,37]. The sequence comparison revealed several potential TFBs in the CLCuBuV LIR region, such as the E-box motifs (CANNTG) [38] at sites $+21,+77,+220,-21,-77$, and -220 and the maize DOF transcription factor recognition core sequence AAAG [39] at sites $+141,+234,-4,-32$, and -129 . The TATA and CAAT boxes are located at $+141,+234,-4,-32$, and -129 . The CARGCW8GAT (CWWWWWWWWG) motif, which are responsible for regulating nectory-specific gene expression, at positions $+61,+256,-61$, and -256 . The plant polyA signal consensus sequence POLASIG3 motif (AATAAT) was also identified at position +242 . Other potential plant cis-regulatory DNA elements and TFBs that were identified searching the PlantCARE and PLACE databases are listed in Tables 1 and 2. 
Figure 2. (A) Genome organization of the DNA-A component of CLCuBuV. Five ORFs are shown with the arrows. V1 and V2 (coat protein) are located on the plus strand, C1 (replication associated protein), C3 (replication enhancer protein) and C4 (unnamed) are located on the complementary sense strand. The 455 bp large intergenic region (LIR) contains the potential stem-loop with nonanucleotides conserved among all geminiviruses. Sequence numbering begins at base 8 of the conserved nonamer; (B) A schematic drawing of the $\mathrm{CLCuBuV}$ LIR. Shown, is the invariant loop sequence with the nonanucleotide sequence (grey box) flanked by inverted repeats (short arrows); the viral protein start sites and replication associated proteins; (C) A schematic representation of both expression vectors shows the cloning of the $\mathrm{C} 1$ and V1 promoters; (D) Schematic representation of important features of large intergenic region (LIR) of $\mathrm{CLCuBuV}$ including REP-binding sites (iterons), TATA box and structure of hair pin showing nonanucleotide (underlined). The TATA box for Rep promoter was to be present at position 2660-2664 in the genome. Two directly repeats iteron motifs AAATTC were predicted at position 2709-2715; 2715-2721 present downstream to TATA box and immediate upstream to stem-loop motif. The stem-loop motif composed of 35 bp was predicted at position 2738-15 in the CLCuBuV genome.

A

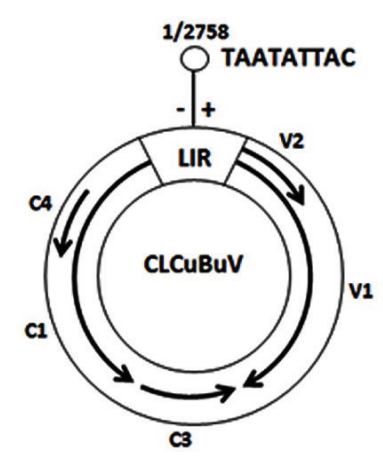

LIR

B

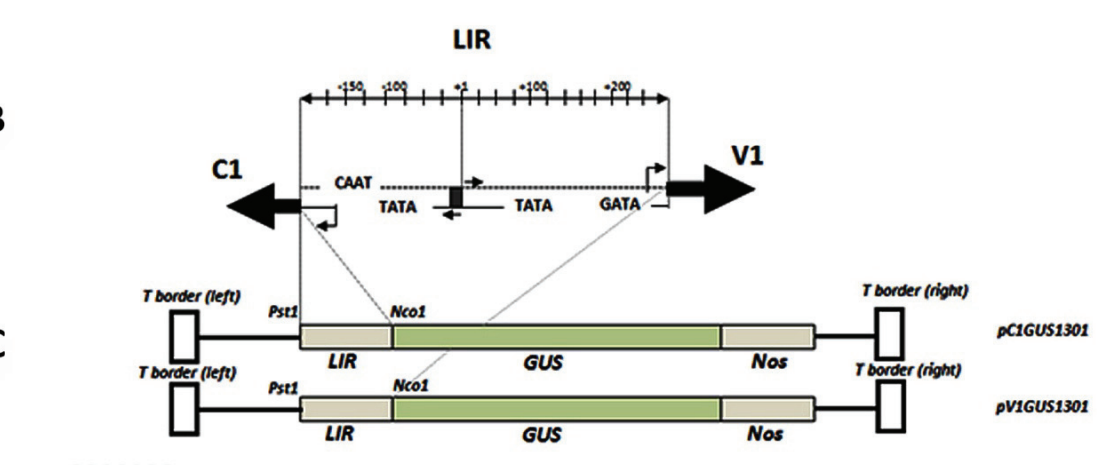

D

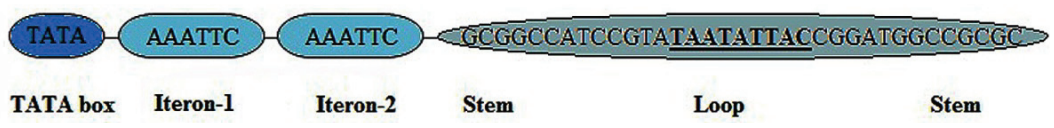


Table 1. List of putative cis-regulatory elements found in the large intergenic region (LIR) of $\mathrm{CLCuBuV}$.

\begin{tabular}{|c|c|c|c|c|c|c|}
\hline No. & TFBs $^{a}$ & $\begin{array}{l}\text { Function of } \\
\text { the motif }\end{array}$ & organism & Sequence & Strand & Position \\
\hline \multirow{2}{*}{1} & \multirow{2}{*}{ Box-I } & \multirow{2}{*}{$\mathrm{LRE}^{\mathrm{b}}$} & \multirow{2}{*}{ Pisum sativum } & TTTCAAA & - & 110 \\
\hline & & & & TTTCAAA & - & 286 \\
\hline 2 & Box-II & LRE & Solanum tubersum & TGGTAATAA & + & 433 \\
\hline 3 & Box-W1 & $\begin{array}{c}\text { Fungal elicitor } \\
\text { RE }\end{array}$ & $\begin{array}{l}\text { Petroselinum } \\
\text { crispum }\end{array}$ & TTGACC & - & 7 \\
\hline 4 & C-Repeat/DRE & $\begin{array}{c}\text { Cold and } \\
\text { dehydration RE }\end{array}$ & $\begin{array}{c}\text { Arabidopsis } \\
\text { thaliana }\end{array}$ & TGGCCCGAC & - & 209 \\
\hline 5 & CAAT-box & $\begin{array}{c}\text { Core promoter } \\
\text { elements }\end{array}$ & many & many &,+- & many \\
\hline \multirow{2}{*}{6} & \multirow{2}{*}{ CGCG-box } & \multirow{2}{*}{ Signal RE } & Arabidopsis & ACGCGC & + & 226 \\
\hline & & & thaliana & GCGCGG & - & 173 \\
\hline 7 & CGTCA-motif & MeJA RE & Hordeum vulgare & CGTCA & - & 223 \\
\hline 8 & Circadian & $\begin{array}{c}\text { Circadian } \\
\text { control }\end{array}$ & $\begin{array}{l}\text { Lycopersicon } \\
\text { esculentum }\end{array}$ & CAANNNNATC & - & 178 \\
\hline 9 & ERE & Ethylene RE & $\begin{array}{c}\text { Dianthus } \\
\text { caryophyllus }\end{array}$ & ATTTCAAA & + & 110 \\
\hline 10 & GATA-motif & LRE & $\begin{array}{l}\text { Arabidopsis } \\
\text { thaliana }\end{array}$ & GATA & + & many \\
\hline 11 & G-box & LRE & Triticum aestivum & TCCACATGGCA & + & 74 \\
\hline 12 & GC-motif & unknown & Oryza sativa & GCCGCGCCG & + & 171 \\
\hline \multirow{3}{*}{13} & \multirow{3}{*}{ GT-1motif } & \multirow{3}{*}{ LRE } & Avena sativa & GGTAAT & - & 161 \\
\hline & & & Oryza sativa & GAAAAA & + & 290 \\
\hline & & & Pisum sativum & GGTAAT & + & 435 \\
\hline 14 & HSE & $\mathrm{HSE}^{\mathrm{c}}$ & Brassica oleracea & AGAAAACTT & + & 380 \\
\hline 15 & I-box & LRE & many & many &,+- & many \\
\hline 16 & MBS & $\begin{array}{c}\text { MYB drought } \\
\text { RE }\end{array}$ & $\begin{array}{c}\text { Arabidopsis } \\
\text { thaliana }\end{array}$ & $\begin{array}{l}\text { CAACTG } \\
\text { TAACTG } \\
\text { TAACTG }\end{array}$ & $\begin{array}{l}+ \\
- \\
-\end{array}$ & $\begin{array}{c}20 \\
355 \\
366\end{array}$ \\
\hline 17 & Skn-1_motif & $\begin{array}{c}\text { Endosperm } \\
\text { expression RE } \\
\text { Core elements }\end{array}$ & Oryza sativa & GTCAT & - & 222 \\
\hline 18 & TATA-box & $\begin{array}{c}\text { located at }-30 \\
\text { of TSS }\end{array}$ & many & many &,+- & many \\
\hline 19 & TGACG-motif & MeJA RE & Horedeum volgare & TGACG & + & 223 \\
\hline 20 & W-box & LRE & $\begin{array}{c}\text { Arabidopsis } \\
\text { thaliana }\end{array}$ & TTGACC & - & 7 \\
\hline
\end{tabular}

Both the AC1 and AV1 promoters share common promoter elements. The LIR is flanked by the Rep and virion sense genes. The nucleotide immediately preceding the Rep (C1) gene is numbered 1 ; ${ }^{\mathrm{a}}$ Transcriptional factor binding sites; ${ }^{\mathrm{b}}$ Light responsive elements; ${ }^{\mathrm{c}}$ Heat shock responsive elements. 
Table 2. The putative transcriptional factor binding sites (TFBs) identified from the PLACE database.

\begin{tabular}{|c|c|c|c|c|c|}
\hline TFBs & PLACE ID & $\begin{array}{c}\text { PLACE } \\
\text { accession ID }\end{array}$ & Sequence & $\begin{array}{c}\text { Copy } \\
\text { number }\end{array}$ & Description \\
\hline \multirow{2}{*}{$\begin{array}{l}\text { Cytokinin } \\
\text { related }\end{array}$} & ARFAT(Aux RE) & S000270 & NGATT & 2 & $\begin{array}{l}\text { "ARR1-binding element" found in rice } \\
\text { andArabidopsis;ARR1 is response } \\
\text { regulator; } \mathrm{N}=\mathrm{G} / \mathrm{A} / \mathrm{C} / \mathrm{T}[40]\end{array}$ \\
\hline & ARR1AT & S000454 & TGTCTC & 5 & $\begin{array}{l}\text { "ARF biding site" found in the } \\
\text { promoters of primary/early response } \\
\text { gene }[41]\end{array}$ \\
\hline \multirow[t]{2}{*}{$\begin{array}{l}\text { Auxin } \\
\text { related }\end{array}$} & SURECOREATSULTR11 & S000499 & GAGAC & 8 & $\begin{array}{c}\text { Core of sulfur-responsive element } \\
\text { SURE); containing ARF binding } \\
\text { sequence GAGACA(complementary } \\
\text { AuxRE TGTCTC)[42] }\end{array}$ \\
\hline & CATATGGMSAUR & S000370 & CATATG & 2 & $\begin{array}{l}\text { Multiple auxin response modules in } \\
\text { the soybean SAUR15A promoter [43] }\end{array}$ \\
\hline $\begin{array}{l}\text { Mesophyll- } \\
\text { specific }\end{array}$ & CACTFTPPCA1 & S000449 & YACT & 8 & $\begin{array}{l}\text { Mesophyll-specific gene expression in } \\
\text { C4 plant Flaveria trinervia [44]. }\end{array}$ \\
\hline $\begin{array}{l}\text { Pollen- } \\
\text { specific }\end{array}$ & POLLEN1LELAT52 & S000245 & AGAAA & 1 & $\begin{array}{l}\text { Pollen-specific expression of tomato } \\
\text { Late } 52 \text { gene [45] }\end{array}$ \\
\hline \multirow{2}{*}{$\begin{array}{l}\text { Root- } \\
\text { specific }\end{array}$} & ROOTMOTIFTAPOX1 & S000098 & ATATT & 5 & $\begin{array}{l}\text { Root-specific motifs found in the rolD } \\
\text { promoter [46]. }\end{array}$ \\
\hline & OSE2ROOTNODULE & S000468 & СТСТТ & 1 & $\begin{array}{l}\text { Nodule specificity of soybean } \mathrm{lbc} 3 \text { and } \\
\text { N23 gene promoters [47]. }\end{array}$ \\
\hline
\end{tabular}

\subsection{Transient Expression of the Bidirectional Promoter}

In the agroinfiltration of the leaves in both hosts (cotton and tobacco), the $\mathrm{AC} 1$ promoter construct (pRepGUS1301) revealed Gus-positive expression in vascular and mesophyll cells. The AV1 promoter construct (pCPGUS1301) showed very weak GUS transient expression. The CaMV 35S promoter also displayed high GUS activity levels. There was no difference in the pattern of expression of the AV1 and $\mathrm{AC} 1$ promoters at 48 and $72 \mathrm{~h}$ post-delivery into the plants. To quantify GUS expression, two separate leaves of $N$. tobacum were agroinoculated with each promoter construct in triplicate. Equivalent amounts of protein were harvested and assayed for fluorescence. The CLCuBuVC1 promoter showed higher activity when compared with the CLCuBuV V1 and CaMV 35S promoters, as shown in (Figure 3) GUS activity from each promoter construct was highly uniform in the different leaves. Transient GUS expression from all three constructs was uniform in both host plant leaves. All three constructs were GUS positive in the root hypocotyl axis of the sprouted French bean seeds. The transient expression of the CLCuBuV V1 promoter was very low compared to the CLCuBuV C1 promoter; one or two blue spots were observed microscopically in few explants. To determine whether the CLCuBuVC1 promoter was differentially expressed in other legume hosts, cow pea, and mung bean seedlings were also tested. All three constructs had similar GUS expression levels in these hosts as in the French bean seedlings as shown in (Figure 3). The statistical analysis revealed that there were significant differences $(p<0.05)$ for all promoters. Lowest coefficient of variance was recorded for 
cow pea while higher for French bean. Highest mean performance was recorded for tobacco $(1,320 \pm 441.99)$ while lowest for French bean $(532.72 \pm 247.45)$. The results indicated that $\mathrm{CLCuBuV}$ $\mathrm{C} 1$ promoter performed better as compared to other promoters in all plants while lower performance was recorded for CLCuBuV V1 promoter. The combined effects of all promoters indicated significant differences among the promoters, crops, and their attractions.

Figure 3. Transient GUS expression in plant leaves and roots agro-inoculated with the $\mathrm{AC1}$ and AV1 promoter constructs from CLCuBuV (pV1GUS1301, pC1GUS1301) in comparison with positive control CaM 35S promoter (pCAMBIA1301) and a negative promoterless control (pCAMBIA1391-Z). Error bars represent standard deviation.GUS activity measured in RFU mg ${ }^{-1}$ protein $\min ^{-1}$. Each treatment was carried out in three replications.

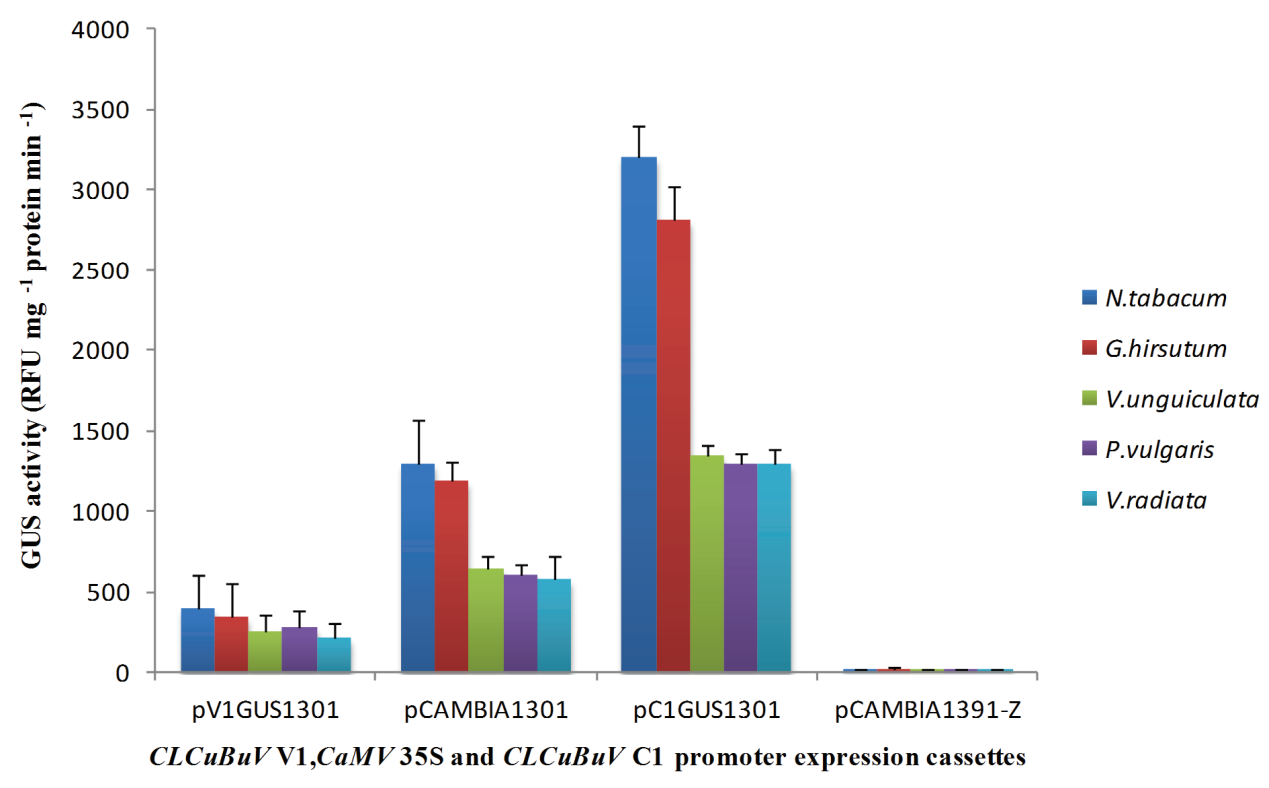

\subsection{Nucleotide Sequence Comparison of the CLCuBuV LIR}

The $455 \mathrm{bp}$ LIR sequence of $\mathrm{CLCuBuV}$ acts as a bidirectional promoter and is homologous to the LIRs from several other $\mathrm{CLCuV}$ isolates. The CLCuBuV LIR showed $81 \%-82 \%$ nucleotide sequence identity with the LIR from CLCukoV, CLCuMuV, and Cotton leaf curl Shahdadpur virus (CLCuShV) but only $32 \%$ and $65.7 \%$ sequence identity with the LIRs from Cotton leaf curl Gezira virus $(\mathrm{CLCuGeV})$ and Cotton leaf curl Alabad virus (CLCuAV), respectively. The nucleotide sequence identities of the CLCuBuV LIR with other begomoviruses are listed in (Table 3). The transcription start site was predicted to be $30 \mathrm{bp}$ downstream of the consensus TATA box. This is consistent with the PlantCARE database results, which indicate that the consensus TATA box is located at the -30 site of TSS, as listed in Table 1. These results are in agreement with a previous study involving the transcript mapping of $\mathrm{CLCuBuV}$ [48]. The A+T content of the CLCuBuV LIR is approximately $60 \%$. The CLCuBuV bidirectional gene promoter showed 70\% nucleotide sequence identity with the WDG [17]. 
Table 3. Nucleotide sequence comparison of the LIR from CLCuBuV with other closely related geminivirus LIRs.

\begin{tabular}{ccccc}
\hline No & Virus Acronym & \% identity $^{\text {a }}$ & LIR size (bp) & Accession IDs \\
\hline 1 & $C L C u B u V$ & 100 & 455 & FR837932 \\
2 & $C L C u M u V$ & 81.8 & 440 & AJ496287 \\
3 & $C L C u K o V$ & 81.6 & 447 & AJ496286 \\
4 & $C L C u S h V$ & 81.9 & 447 & FN552004 \\
5 & $H Y V M V$ & 77.4 & 437 & FR772082 \\
6 & $C L C u B a V$ & 76.4 & 444 & NC_007290 \\
7 & $M a Y V C M V$ & 73.6 & 440 & FR715681 \\
8 & $P a L C u V$ & 70.1 & 478 & FM955602 \\
9 & $A E V$ & 69.9 & 445 & AM698011 \\
10 & $C Y V M V$ & 69.8 & 451 & FN645926 \\
11 & ToLCPKV & 68.1 & 456 & AM948961 \\
12 & $C h i L C M u V$ & 68.7 & 450 & FM149613 \\
13 & SiLCV & 66.9 & 447 & DQ641706 \\
14 & $C L C u A a V$ & 65.2 & 434 & AJ002452 \\
15 & $C L C u R a V$ & 64.6 & 444 & JF502364 \\
16 & $C L C u G e V-P K$ & 32.7 & 453 & FR751142 \\
17 & $C L C u G e V-S D$ & 32.6 & 451 & AY036007 \\
\hline \multicolumn{5}{c}{${ }^{a} \%$ identity with CLCuBuV LIR. } \\
\end{tabular}

\subsection{Enriched Regulatory Elements in the Geminivirus Bidirectional Promoters}

Transgene expression is regulated by the interaction of transcription factors and target cis-regulatory elements in the promoters. The identification of potential regulatory elements acting in the geminivirus bidirectional promoters can be a useful tool to understand the regulatory network. We scanned enriched cis-acting regulatory DNA elements in the bidirectional promoters of CLCuBuV and closely related geminiviruses to determine possible functions. We first analyzed known plant regulatory elements in these promoter sequences using PLACE collection. We used CREs within the LIR of $\mathrm{CLCuBuV}$ and other geminivirus to compare different sequences. The names of 21 broadly distributed CREs and their occurrence in each promoter sequence are shown in Figure 4.

The ranking of these $21 \mathrm{CREs}$ with total occurrence are shown in Figure 5A. The distribution and occurrence of the CREs in the bidirectional promoter of $\mathrm{CLCuBuV}$ is shown in Figure 5B. Several enriched PLACE motifs are universal or structural CREs that are similar to geminivirus bidirectional promoters, such as TATABOX5 [49], POLASIG1, and POLASIG3 [50,51]. Many CREs are environmental responsive motifs, such as MYCCONSENSUSAT for cold [52,53], WRKY71OS for gibberellins and pathogenesis [54,55], IBOXCORE for lights [56,57], MYBCORE for water stress [58], and GT1GMSCAM4 for pathogens and salt [59]. To complement the searches for possible motifs that have a statistically overrepresented frequency in the LIR, we computationally analyzed the closely related promoters using MEME. As a result, six motifs were found enriched within the twelve promoters (Figure 6). 
Figure 4. Occurrence of 21 enriched cis-acting regulatory DNA elements distributed in the 12 bidirectional geminivirus promoters.

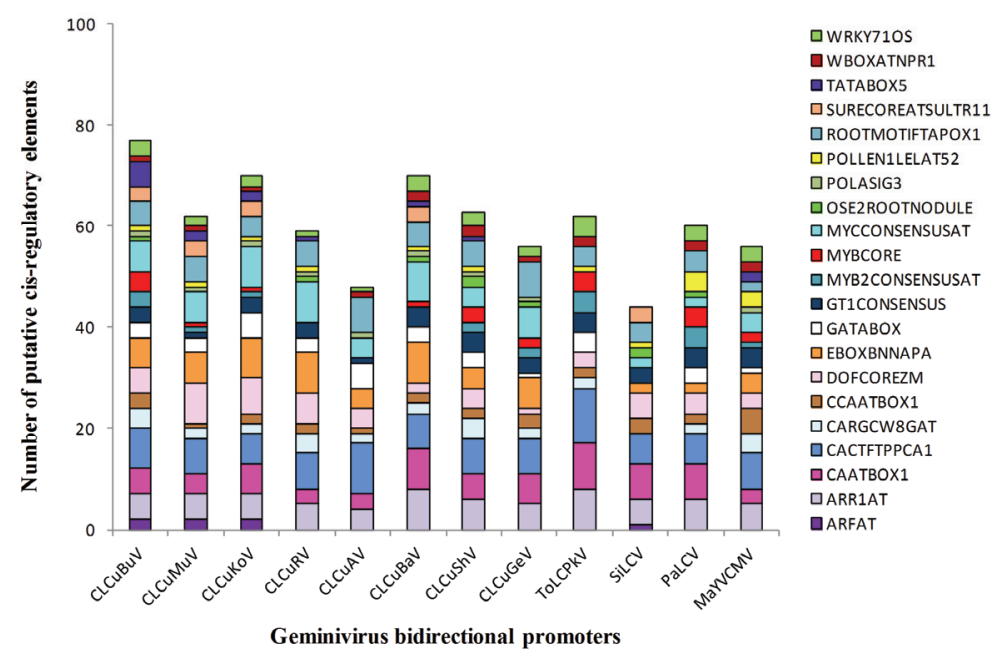

Figure 5. (A) Occurrence of the top 21 CREs with a total occurrence in 12 promoters; (B) Occurrence of $32 \mathrm{CREs}$ distributed in the CLCuBuV bidirectional promoter.

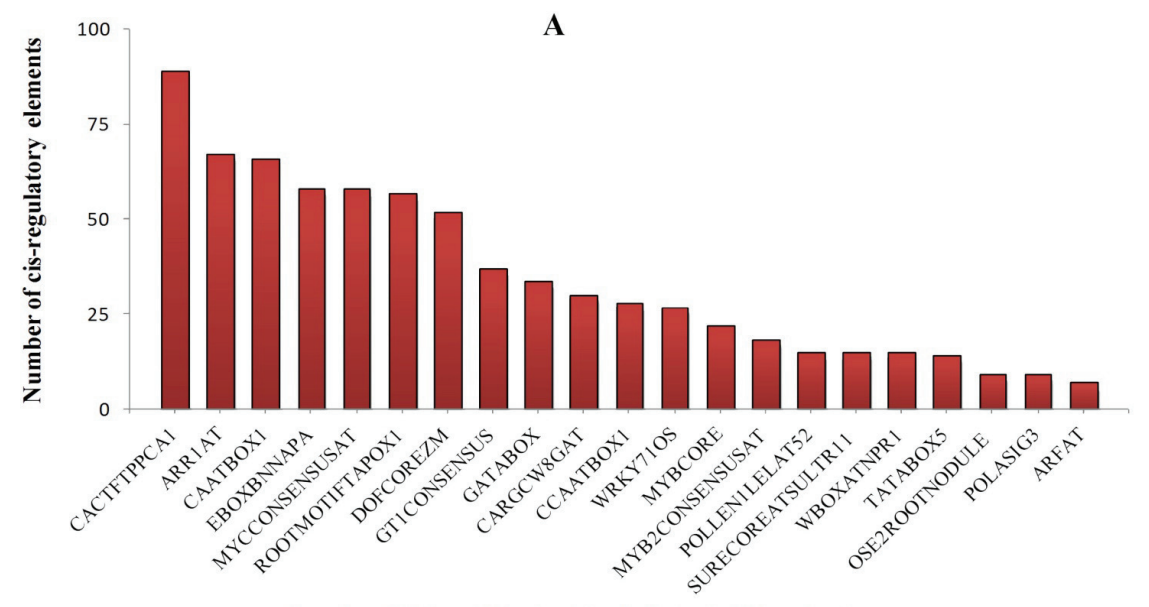

Putative CREs within the Geminivirus bidirectional promoters

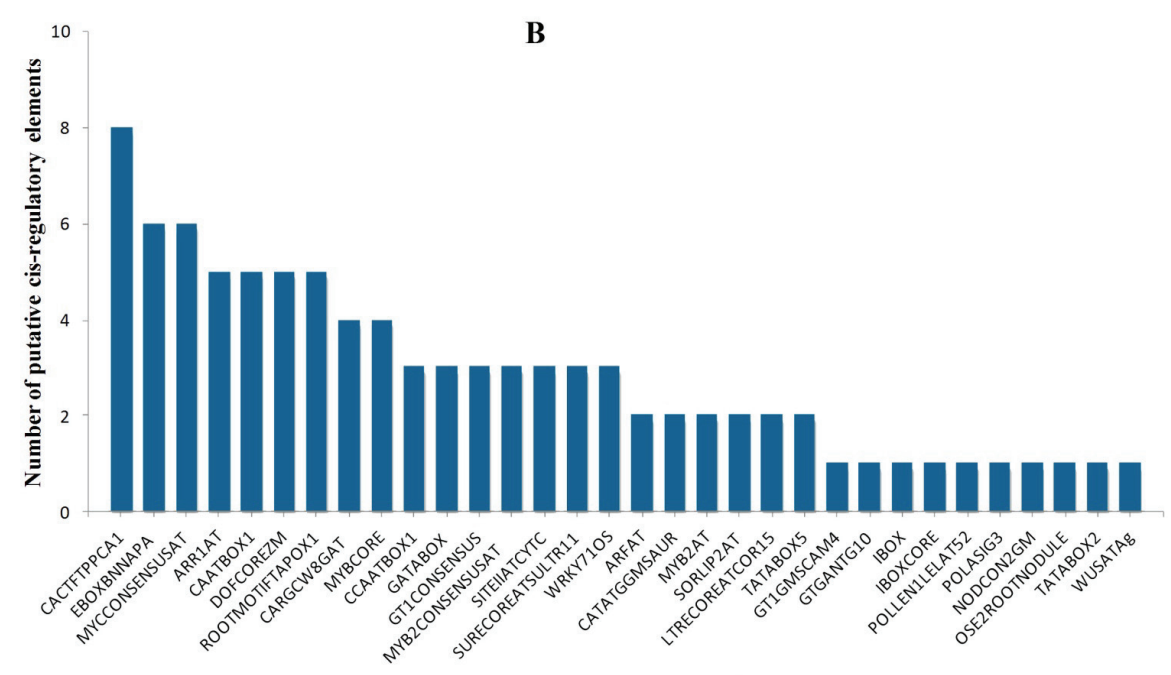

Putative CREs within the CLuBuV bidirectional promoter 
Figure 6. Overrepresented sequences in the bidirectional promoters of geminiviruses used in this study. Letters abbreviating the nucleotides $(A, C, G, T)$ in the images are sized to their relative occurrence. (A) MNB1A motif (MA0053.1) $p$-value 3.1e-075 belongs to Zinc-coordinating class and Dof family; (B) HAP4 motif (MA0315.1) $p$-value 4.2e-027; (C) HAP5 motif (MA0316.1) $p$-value 7.33e-05; (D) NFYA motif (MA0060.1) $p$-value 5.3e-06; (E) PBF motif (MA0064.1) $p$-value 1.4e-017 belongs to Zinc-coordinating class and Dof family; (F) HAP3 motif (MA 00314.1) $p$-value 1.2e-07. All HAP motifs belong to Alpha Helix class and NFY CCAAT-binding family.
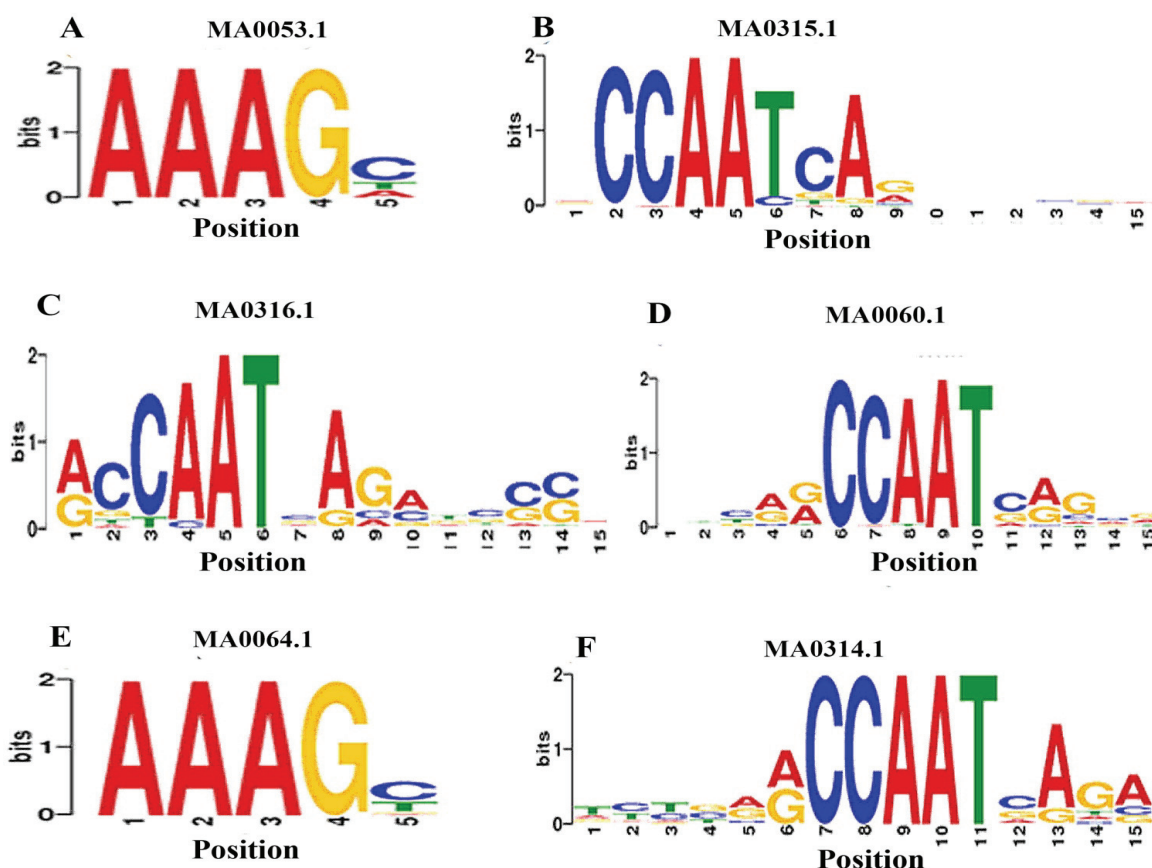

MA0060.1
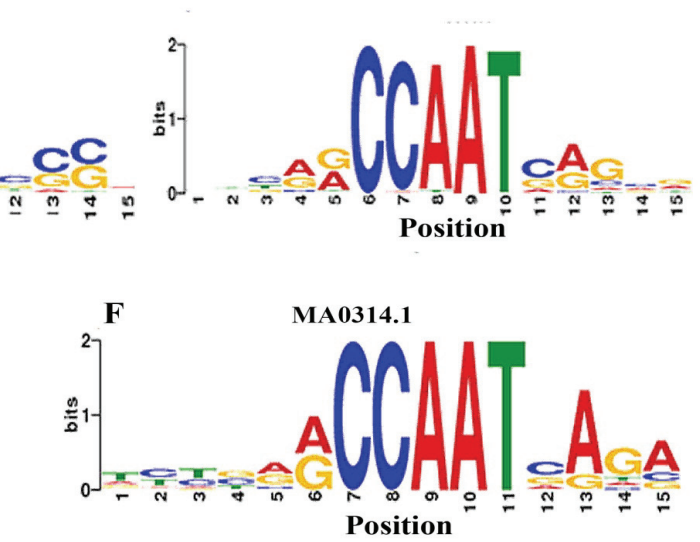

\subsection{Identification of TFBs that Bind to the Promoters of ds-DNA Animal Viruses}

The TFBs in various organisms were searched for in the databases to determine more regulatory elements in the large intergenic region of $\mathrm{CLCuBuV}$. Apart from the sites for TFs that bind to promoter elements, more than 40 TFBs were identified in plants, mammals and yeast. The binding sites of TFs that bind to the promoters of certain ds-DNA animal viruses were also found, such as CRF and NF-1, which bind to the E2 late promoter [60] and early gene (E1A) [61], respectively, of adenoviruses; Cx and NF-Y, which bind to immediate early gene-3 (IE-3) [62] and thymidine kinase [63], respectively, of herpes simplex virus (HSV-1); and T-Ag that binds to Polyoma viruses [64].

\section{Discussion}

Agrobacterium-mediated transient transformation has been used to analyze foreign gene expression [65-68], gene silencing [69,70], and gene interactions [71-73]. More recently, the Agrobacterium-mediated transient expression assay has been demonstrated to be a simple and efficient method for the quantitative analysis of plant promoter and cis-element/trans-factor interactions in vivo [74]. In a previous study, our group has characterized the cotton universal stress protein 
promoter and cotton heat shock protein promoter in response to abiotic stresses in tobacco using the Agrobacterium-mediated transient assay [75,76]. We utilized six-week old tobacco leaves for agro-infiltration because of the excellent transformation efficiency and minimization of assay variation [74].

In this study, the LIR sequence of the DNA-A component of the CLCuBuV genome was isolated and analyzed. In the transient expression assay with tobacco and cotton leaves, the CLCuBuV C1 promoter displayed strong GUS activity, while the CLCuBuV V1 promoter displayed weak activity in the absence of the $\mathrm{C} 2$ (Trap) gene product. CLCuBuV lacks the transcriptional activator protein $\mathrm{C} 2$ (Trap) [23,25]. The GUS quantitative assay revealed that $\mathrm{CLCuBuV} \mathrm{C1}$ promoter activity was two- to three-fold higher than the CaMV 35S promoter, while the activity of CLCuBuV V1 was three- to four-fold lower than the CaMV 35S promoter. It has been reported that virion sense promoters need trans-activator $\mathrm{AC} 2 / \mathrm{C} 2$ [77,78]. The superiority of the $\mathrm{C} 1 / \mathrm{AC} 1$ promoter compared to the V1/AV1 promoter in the absence of transcriptional activator protein C2 (Trap) was also reported in ACMV [12], wheat dwarf virus (WDV) [79], CLCuMuV [4], and MYMIY [18]. We have previously characterized the DNA-A component of the CLCuBuV genome and phylogenetically analyzed the LIR, which displayed homology with the LIRs from CLCuKoV and CLCuMuV [25]. The transient GUS expression analysis of $\mathrm{CLCuBuV} \mathrm{C} 1$ and $\mathrm{V} 1$ in this study is consistent with the CLCuMuV C1 promoter, which displayed four- to five-fold higher GUS activity than the CaMV 35S promoter in transgenic tobacco plants [4]. Similar to other geminiviruses, $\mathrm{CLCuBuV}$ produces multiple overlapping polycistronic RNA species that diverge from the LIR, confirming a bidirectional transcriptional strategy. The TATA and CAAT boxes are located approximately $30 \mathrm{bp}$ from the transcription initiation site (TIS), which is consistent with a previous study involving the long complementary sense transcript mapping of $\mathrm{CLCuBuV}$ [48]. This previous study suggested that $\mathrm{CLCuBuV}$ uses a bicistronic transcription strategy to translate C2 and REn (replication enhancer protein) from a single transcript $[48,80]$. The homologous regulatory modules responsive to light, heat, wounds, hormones, and salicylic acid that have been identified in different monocots and dicots were found in the bidirectional promoter of $\mathrm{CLCuBuV}$. The transcription regulation of geminiviruses share many common features with papavoviruses and adenoviruses. In that context the presence of TF binding sites in the CLCuBuV bidirectional promoter that are also found in adenoviruses and papavoviruses gain significance. Though hundreds of begomoviruses have been cloned and sequenced, analysis of promoters had been carried out for only few begomoviruses. The information that we have generated on the bidirectional promoter of $\mathrm{CLCuBuV}$, a very distinct newly emerged Old World begomovirus would help in further elucidating transcription regulation in begomoviruses. The expression of RNAi construct (hairpin) of LIR of $\mathrm{CLCuBuV}$ to control Cotton leaf curl disease (CLCuD) and expression of an insecticidal gene (Cry1 Ac) under the $\mathrm{CLCuBuV} \mathrm{C1}$ promoter in transgenic cotton are in progress.

\section{Conclusions}

In conclusion, we have computationally characterized the bidirectional gene promoter from $\mathrm{CLCuBuV}$ and 11 other closely related geminiviruses that specifically drive gene expression. These findings provide important tools for transgene expression studies and crop breeding. Particularly, of 
the promoters studied, $\mathrm{CLCuBuV} \mathrm{C1}$ is a prime candidate for high gene expression, which is desired in green tissues, using recombinant DNA technology.

\section{Acknowledgments}

This work was supported by (i) Higher Education Commission (HEC) Pakistan under the "Indigenous $5000 \mathrm{PhD}$ Fellowship Program (Batch-IV)" and (ii) ICARDA PAK-USDA project ID-1198. The acknowledgements are also due to Muhammad Ashraf Saeed from Chak No.59/F-Hasilpur for providing tobacco seedlings, to Muhammad Shahzad Latif (CEMB) for assistance in statistical analysis and to Azeem Mehmood Butt (CEMB) for assistance in manuscript preparation.

\section{Conflicts of Interest}

The authors declare no conflict of interest.

\section{References and Notes}

1. Fauquet, C.; Briddon, R.; Brown, J.; Moriones, E.; Stanley, J.; Zerbini, M.; Zhou, X. Geminivirus strain demarcation and nomenclature. Arch. Virol. 2008, 153, 783-821.

2. Stanley, J.B.D.M.; Briddon, R.W.; Brown, J.K.; Fauquet, C.M.; Geminiviridae. In Virus Taxonomy, Viith Report of the Ictv; Fauquet, C.M., Mayo, M.A., Maniloff, J., Desselberger, U., Ball, L.A., Eds.; Elsevier/Academic Press: London, UK, 2005; pp. 301-326.

3. Odell, J.T.; Nagy, F.; Chua, N.-H. Identification of DNA sequences required for activity of the cauliflower mosaic virus 35s promoter. Nature 1985, 313, 810-812.

4. Xie, Y.; Liu, Y.; Meng, M.; Chen, L.; Zhu, Z. Isolation and identification of a super strong plant promoter from cotton leaf curl multan virus. Plant Mol. Biol. 2003, 53, 1-14.

5. Pattanaik, S.; Dey, N.; Bhattacharyya, S.; Maiti, I.B. Isolation of full-length transcript promoter from the strawberry vein banding virus (SVBV) and expression analysis by protoplasts transient assays and in transgenic plants. Plant Sci. 2004, 167, 427-438.

6. Hanley-Bowdoin, L.; Settlage, S.B.; Orozco, B.M.; Nagar, S.; Robertson, D. Geminiviruses: Models for plant DNA replication, transcription, and cell cycle regulation. Crit. Rev. Plant Sci. 1999, 18, 71-106.

7. Accotto, G.P.; Donson, J.; Mullineaux, P. Mapping of digitaria streak virus transcripts reveals different RNA species from the same transcription unit. EMBO J. 1989, 8, 1033-1039.

8. Petty, I.; Coutts, R.; Buck, K. Transcriptional mapping of the coat protein gene of tomato golden mosaic virus. J. Gen. Virol. 1988, 69, 1359-1365.

9. Sunter, G.; Bisaro, D.M. Transcription map of the B genome component of tomato golden mosaic virus and comparison with a component transcripts. Virology 1989, 173, 647-655.

10. Sunter, G.; Hartitz, M.D.; Bisaro, D.M. Tomato golden mosaic virus leftward gene expression: Autoregulation of geminivirus replication protein. Virology 1993, 195, 275-280.

11. Sunter, G.; Bisaro, D.M. Identification of a minimal sequence required for activation of the tomato golden mosaic virus coat protein promoter in protoplasts. Virology 2003, 305, 452-462. 
12. Zhan, X.; Haley, A.; Richardson, K.; Morris, B. Analysis of the potential promoter sequences of african cassava mosaic virus by transient expression of the beta-glucuronidase gene. J. Gen. Virol. 1991, 72, 2849-2852.

13. Haley, A.; Zhan, X.; Richardson, K.; Head, K.; Morris, B. Regulation of the activities of African cassava mosaic virus promoters by the AC1, AC2, and AC3 gene products. Virology 1992, 188, 905-909.

14. Hong, Y.; Stanley, J. Regulation of African cassava mosaic virus complementary-sense gene expression by $N$-terminal sequences of the replication-associated protein AC1. J. Gen. Virol. 1995, 76, 2415-2422.

15. Frey, P.M.; Schärer-Hernández, N.G.; Fütterer, J.; Potrykus, I.; Puonti-Kaerlas, J. Simultaneous analysis of the bidirectional African cassava mosaic virus promoter activity using two different luciferase genes. Virus Genes 2001, 22, 231-242.

16. Fenoll, C.; Black, D.M.; Howell, S.H. The intergenic region of maize streak virus contains promoter elements involved in rightward transcription of the viral genome. EMBO J. 1988, 7 , 1589-1596.

17. Dinant, S.; Ripoll, C.; Pieper, M.; David, C. Phloem specific expression driven by wheat dwarf geminivirus V-sense promoter in transgenic dicotyledonous species. Physiol. Plant. 2004, 121, $108-116$.

18. Usharani, K.; Periasamy, M.; Malathi, V. Studies on the activity of a bidirectional promoter of Mungbean yellow mosaic India virus by agroinfiltration. Virus Res. 2006, 119, 154-162.

19. Sunitha, S.; Mahajan, N.; Veluthambi, K. The TrAP/REn monodirectional promoter of Mungbean yellow mosaic geminivirus (MYMV) displays root-specific expression in transgenic tobacco. Plant Cell 2012, 109, 535-545.

20. Eagle, P.A.; Hanley-Bowdoin, L. cis Elements that contribute to geminivirus transcriptional regulation and the efficiency of DNA replication. J. Virol. 1997, 71, 6947-6955.

21. Argüello-Astorga, G.; Guevara-Gonzalez, R.; Herrera-Estrella, L.; Rivera-Bustamante, R. Geminivirus replication origins have a group-specific organization of iterative elements: A model for replication. Virology 1994, 203, 90-100.

22. Eagle, P.A.; Orozco, B.M.; Hanley-Bowdoin, L. A DNA sequence required for geminivirus replication also mediates transcriptional regulation. Plant Cell 1994, 6, 1157-1170.

23. Amrao, L.; Amin, I.; Shahid, M.S.; Briddon, R.W.; Mansoor, S. Cotton leaf curl disease in resistant cotton is associated with a single begomovirus that lacks an intact transcriptional activator protein. Virus Res. 2010, 152, 153-163.

24. Nawaz-ul-Rehman, M.S.; Briddon, R.W.; Fauquet, C.M. A melting pot of old world begomoviruses and their satellites infecting a collection of Gossypium species in Pakistan. PLoS One 2012, 7, e40050.

25. Ashraf, M.A.; Shahid, A.A.; Mohamed, B.B.; Dahab, A.A.; Bajwa, K.S.; Rao, A.Q.; Khan, M.A.U.; Ilyas, M.; Haider, M.S.; Husnain, T. Molecular characterization and phylogenetic analysis of a variant of highly infectious cotton leaf curl Burewala virus associated with CLCuD from Pakistan. Aust. J. Crop Sci. 2013, 7, 1113-1122.

26. Mullineaux, P.M.; Rigden, J.E.; Dry, I.B.; Krake, L.R.; Rezaian, M.A. Mapping of the polycistronic RNAs of tomato leaf curl geminivirus. Virology 1993, 193, 414-423. 
27. Dry, I.; Krake, L.; Mullineaux, P.; Rezaian, A. Regulation of tomato leaf curl viral gene expression in host tissues. Mol. Plant Microbe Interact. 2000, 13, 529-537.

28. Untergasser, A.; Cutcutache, I.; Koressaar, T.; Ye, J.; Faircloth, B.C.; Remm, M.; Rozen, S.G. Primer3-New capabilities and interfaces. Nucleic Acids Res. 2012, 40, e115.

29. Lescot, M.; Déhais, P.; Thijs, G.; Marchal, K.; Moreau, Y.; van de Peer, Y.; Rouzé, P.; Rombauts, S. Plantcare, a database of plant cis-acting regulatory elements and a portal to tools for in silico analysis of promoter sequences. Nucleic Acids Res. 2002, 30, 325-327.

30. Higo, K.; Ugawa, Y.; Iwamoto, M.; Korenaga, T. Plant cis-acting regulatory DNA elements (place) database: 1999. Nucleic Acids Res. 1999, 27, 297-300.

31. Wingender, E.; Dietze, P.; Karas, H.; Knüppel, R. Transfac: A database on transcription factors and their DNA binding sites. Nucleic Acids Res. 1996, 24, 238-241.

32. Reese, M.G. Application of a time-delay neural network to promoter annotation in the Drosophila melanogaster genome. Comput. Chem. 2001, 26, 51-56.

33. Bailey, T.L.; Boden, M.; Buske, F.A.; Frith, M.; Grant, C.E.; Clementi, L.; Ren, J.; Li, W.W.; Noble, W.S. Meme suite: Tools for motif discovery and searching. Nucleic Acids Res. 2009, 37, W202-W208.

34. Portales-Casamar, E.; Thongjuea, S.; Kwon, A.T.; Arenillas, D.; Zhao, X.; Valen, E.; Yusuf, D.; Lenhard, B.; Wasserman, W.W.; Sandelin, A. Jaspar 2010: The greatly expanded open-access database of transcription factor binding profiles. Nucleic Acids Res. 2010, 38, D105-D110.

35. Bradford, M.M. A rapid and sensitive method for the quantitation of microgram quantities of protein utilizing the principle of protein-dye binding. Anal. Biochem. 1976, 72, 248-254.

36. Fenoll, C.; Schwarz, J.J.; Black, D.M.; Schneider, M.; Howell, S.H. The intergenic region of maize streak virus contains a GC-rich element that activates rightward transcription and binds maize nuclear factors. Plant Mol. Biol. 1990, 15, 865-877.

37. Ruiz-Medrano, R.; Guevara-Gonzalez, R.; Argüello-Astorga, G.; Monsalve-Fonnegra, Z.; Herrera-Estrella, L.; Rivera-Bustamante, R. Identification of a sequence element involved in AC2-mediated transactivation of the pepper huasteco virus coat protein gene. Virology 1999, 253, $162-169$.

38. Schwarz, J.J.; Chakraborty, T.; Martin, J.; Zhou, J.; Olson, E.N. The basic region of myogenin cooperates with two transcription activation domains to induce muscle-specific transcription. Mol. Cell. Biol. 1992, 12, 266-275.

39. Yanagisawa, S.; Schmidt, R.J. Diversity and similarity among recognition sequences of Dof transcription factors. Plant J. 1999, 17, 209-214.

40. Ross, E.J.; Stone, J.M.; Elowsky, C.G.; Arredondo-Peter, R.; Klucas, R.V.; Sarath, G. Activation of the Oryza sativa non-symbiotic haemoglobin-2 promoter by the cytokinin-regulated transcription factor, arr1. J. Exp. Botany 2004, 55, 1721-1731.

41. Goda, H.; Sawa, S.; Asami, T.; Fujioka, S.; Shimada, Y.; Yoshida, S. Comprehensive comparison of auxin-regulated and brassinosteroid-regulated genes in Arabidopsis. Plant Physiol. 2004, 134, 1555-1573.

42. Maruyama-Nakashita, A.; Nakamura, Y.; Watanabe-Takahashi, A.; Inoue, E.; Yamaya, T.; Takahashi, H. Identification of a novel cis-acting element conferring sulfur deficiency response in Arabidopsis roots. Plant. J. 2005, 42, 305-314. 
43. Xu, N.; Hagen, G.; Guilfoyle, T. Multiple auxin response modules in the soybean SAUR 15A promoter. Plant Sci. 1997, 126, 193-201.

44. Gowik, U.; Burscheidt, J.; Akyildiz, M.; Schlue, U.; Koczor, M.; Streubel, M.; Westhoff, P. cis-Regulatory elements for mesophyll-specific gene expression in the $\mathrm{C} 4$ plant Flaveria trinervia, the promoter of the $\mathrm{C} 4$ phosphoenolpyruvate carboxylase gene. Plant Cell 2004, 16, 1077-1090.

45. Filichkin, S.A.; Leonard, J.M.; Monteros, A.; Liu, P.-P.; Nonogaki, H. A novel endo- $\beta$-mannanase gene in tomato LeMAN5 is associated with anther and pollen development. Plant Physiol. 2004, 134, 1080-1087.

46. Elmayan, T.; Tepfer, M. Evaluation in tobacco of the organ specificity and strength of therold promoter, domain a of the 35S promoter and the $35 \mathrm{~S}^{2}$ promoter. Transgenic Res. 1995, 4, 388-396.

47. Stougaard, J.; Jørgensen, J.-E.; Christensen, T.; Kühle, A.; Marcker, K.A. Interdependence and nodule specificity of cis-acting regulatory elements in the soybean leghemoglobin lbc 3 and N23 gene promoters. Mol. Gen. Genet. 1990, 220, 353-360.

48. Akbar, F.; Briddon, R.W.; Vazquez, F.; Saeed, M. Transcript mapping of cotton leaf curl burewala virus and its cognate betasatellite, cotton leaf curl multan betasatellite. Virol. J. 2012, 9, doi:10.1186/1743-422X-9-249.

49. Tjaden, G.; Edwards, J.W.; Coruzzi, G.M. cis Elements and trans-acting factors affecting regulation of a nonphotosynthetic light-regulated gene for chloroplast glutamine synthetase. Plant Physiol. 1995, 108, 1109-1117.

50. Joshi, C.P. Putative polyadenylation signals in nuclear genes of higher plants: A compilation and analysis. Nucleic Acids Res. 1987, 15, 9627-9640.

51. O’Neill, S.D.; Kumagai, M.H.; Majumdar, A.; Huang, N.; Sutliff, T.D.; Rodriguez, R.L. The $\alpha$-amylase genes in Oryza sativa: Characterization of cDNA clones and mRNA expression during seed germination. Mol. Gen. Genet. 1990, 221, 235-244.

52. Abe, H.; Urao, T.; Ito, T.; Seki, M.; Shinozaki, K.; Yamaguchi-Shinozaki, K. Arabidopsis AtMYC2 (bHLH) and AtMYB2 (MYB) function as transcriptional activators in abscisic acid signaling. Plant Cell 2003, 15, 63-78.

53. Hartmann, U.; Sagasser, M.; Mehrtens, F.; Stracke, R.; Weisshaar, B. Differential combinatorial interactions of cis-acting elements recognized by R2R3-MYB, BZIP, and bHLH factors control light-responsive and tissue-specific activation of phenylpropanoid biosynthesis genes. Plant Mol. Biol. 2005, 57, 155-171.

54. Eulgem, T.; Rushton, P.J.; Schmelzer, E.; Hahlbrock, K.; Somssich, I.E. Early nuclear events in plant defence signalling: Rapid gene activation by WRKY transcription factors. EMBO J. 1999, $18,4689-4699$.

55. Zhang, Z.-L.; Xie, Z.; Zou, X.; Casaretto, J.; Ho, T.-h.D.; Shen, Q.J. A rice WRKY gene encodes a transcriptional repressor of the gibberellin signaling pathway in aleurone cells. Plant Physiol. 2004, 134, 1500-1513.

56. Bovy, A.; van den Berg, C.; de Vrieze, G.; Thompson, W.F.; Weisbeek, P.; Smeekens, S. Light-regulated expression of the Arabidopsis thaliana ferredoxin gene requires sequences upstream and downstream of the transcription initiation site. Plant Mol. Biol. 1995, 27, 27-39. 
57. Simpson, S.D.; Nakashima, K.; Narusaka, Y.; Seki, M.; Shinozaki, K.; Yamaguchi-Shinozaki, K. Two different novel cis-acting elements of erd1, a clpA homologous Arabidopsis gene function in induction by dehydration stress and dark-induced senescence. Plant J. 2003, 33, 259-270.

58. Urao, T.; Yamaguchi-Shinozaki, K.; Urao, S.; Shinozaki, K. An Arabidopsis MYB homolog is induced by dehydration stress and its gene product binds to the conserved MYB recognition sequence. Plant Cell 1993, 5, 1529-1539.

59. Park, H.C.; Kim, M.L.; Kang, Y.H.; Jeon, J.M.; Yoo, J.H.; Kim, M.C.; Park, C.Y.; Jeong, J.C.; Moon, B.C.; Lee, J.H.; et al. Pathogen- and NACL-induced expression of the SCaM-4 promoter is mediated in part by a GT-1 box that interacts with a GT-1-like transcription factor. Plant Physiol. 2004, 135, 2150-2161.

60. Goding, C.; Temperley, S.; Fisher, F. Multiple transcription (actors interact with the adenovirus-2 EII-late promoter: Evidence for a novel CCAAT recognition factor. Nucleic Acids Res. 1987, 15, 7761-7780.

61. Koikeda, S.; Ibuki, R.; Sawada, Y.; Nagata, K.; Shibata, H.; Masamune, Y.; Nakanishi, Y. Nuclear factor I stimulates transcription of the adenovirus 12 E1A gene in a cell-free system. Biochim. Biophys. Acta 1990, 1048, 85-92.

62. Bovolenta, C.; Tognon, M.; Liboi, E. Epidermal growth factor induces, in the EL alpha 4-2 cell line, herpes simplex virus-1 alpha 4 gene transcription in the absence of the viral trans-activator VP16. Virus Res. 1991, 19, 199-208.

63. Dorn, A.; Bollekens, J.; Staub, A.; Benoist, C.; Mathis, D. A multiplicity of CCAAT box-binding proteins. Cell 1987, 50, 863-872.

64. Cowie, A.; Kamen, R. Multiple binding sites for polyomavirus large T antigen within regulatory sequences of polyomavirus DNA. J. Virol. 1984, 52, 750-760.

65. Kapila, J.; de Rycke, R.; van Montagu, M.; Angenon, G. An Agrobacterium-mediated transient gene expression system for intact leaves. Plant Sci. 1997, 122, 101-108.

66. Leckie, B.M.; Neal Stewart, C., Jr. Agroinfiltration as a technique for rapid assays for evaluating candidate insect resistance transgenes in plants. Plant Cell Rep. 2011, 30, 325-334.

67. Li, J.F.; Nebenfuhr, A. FAST technique for Agrobacterium-mediated transient gene expression in seedlings of Arabidopsis and other plant species. Cold Spring Harb. Protoc. 2010, 2010, doi:10.1101/pdb.prot5428.

68. Zheng, L.; Liu, G.; Meng, X.; Li, Y.; Wang, Y. A versatile Agrobacterium-mediated transient gene expression system for herbaceous plants and trees. Biochem. Genet. 2012, 50, 761-769.

69. Baulcombe, D.C. Gene silencing: RNA makes RNA makes no protein. Curr. Biol. 1999, 9 , R599-R601.

70. Bhaskar, P.B.; Venkateshwaran, M.; Wu, L.; Ane, J.M.; Jiang, J. Agrobacterium-mediated transient gene expression and silencing: A rapid tool for functional gene assay in potato. PLoS One 2009, 4, e5812.

71. Scofield, S.R.; Tobias, C.M.; Rathjen, J.P.; Chang, J.H.; Lavelle, D.T.; Michelmore, R.W.; Staskawicz, B.J. Molecular basis of gene-for-gene specificity in bacterial speck disease of tomato. Science 1996, 274, 2063-2065. 
72. Frederick, R.D.; Thilmony, R.L.; Sessa, G.; Martin, G.B. Recognition specificity for the bacterial avirulence protein AvrPto is determined by Thr-204 in the activation loop of the tomato Pto kinase. Mol. Cell 1998, 2, 241-245.

73. Tsuda, K.; Qi, Y.; Nguyen le, V.; Bethke, G.; Tsuda, Y.; Glazebrook, J.; Katagiri, F. An efficient Agrobacterium-mediated transient transformation of Arabidopsis. Plant J. 2012, 69, 713-719.

74. Yang, Y.; Li, R.; Qi, M. In vivo analysis of plant promoters and transcription factors by agroinfiltration of tobacco leaves. Plant J. 2000, 22, 543-551.

75. Zahur, M.; Maqbool, A.; Irfan, M.; Barozai, M.Y.K.; Rashid, B.; Riazuddin, S.; Husnain, T. Isolation and functional analysis of cotton universal stress protein promoter in response to phytohormones and abiotic stresses. Mol. Biol. 2009, 43, 578-585.

76. Zahur, M.; Maqbool, A.; Irfan, M.; Barozai, M.Y.K.; Qaiser, U.; Rashid, B.; Husnain, T.; Riazuddin, S. Functional analysis of cotton small heat shock protein promoter region in response to abiotic stresses in tobacco using Agrobacterium-mediated transient assay. Mol. Biol. Rep. 2009, $36,1915-1921$.

77. Sunter, G.; Hartitz, M.D.; Hormuzdi, S.G.; Brough, C.L.; Bisaro, D.M. Genetic analysis of tomato golden mosaic virus: ORF AL2 is required for coat protein accumulation while ORF AL3 is necessary for efficient DNA replication. Virology 1990, 179, 69-77.

78. Hong, Y.; Saunders, K.; Hartley, M.R.; Stanley, J. Resistance to geminivirus infection by virus-induced expression of dianthin in transgenic plants. Virology 1996, 220, 119-127.

79. Hofer, J.; Dekker, E.L.; Reynolds, H.V.; Woolston, C.J.; Cox, B.S.; Mullineaux, P.M. Coordinate regulation of replication and virion sense gene expression in wheat dwarf virus. Plant Cell 1992, 4, 213-223.

80. Shivaprasad, P.; Akbergenov, R.; Trinks, D.; Rajeswaran, R.; Veluthambi, K.; Hohn, T.; Pooggin, M.M. Promoters, transcripts, and regulatory proteins of Mungbean yellow mosaic geminivirus. J. Virol. 2005, 79, 8149-8163.

(C) 2014 by the authors; licensee MDPI, Basel, Switzerland. This article is an open access article distributed under the terms and conditions of the Creative Commons Attribution license (http://creativecommons.org/licenses/by/3.0/). 